\title{
PARAMETRIC STUDY ON POLYSTYRENE SHEET IN CONCRETE
}

\section{GANDHI DHRUMIL \& UNNATI SONI}

Department of Civil Engineering, Parul Institute of Engineering and Technology, Vadodara, India

Now a days, we all are feeling higher degree of heat in concrete building. So, it is necessary to find solution to reduce temperature of house. The solution is, we can use polystyrene sheet in concrete block, which can help to reduce temperature inside the house. But at a same time, we are facing problem with the compressive strength. So, we are using glass fiber to improve compressive strength. In this study, we have usedM20, M25, M30, M35 grade of concrete. Also, we have used Alccofine 1203 in concrete to improve bonding between concrete \& polystyrene. In this study, we have used expanded polystyrene sheet between concrete layers and prepared a "Thermoblock". Ultimately we have tested this block for compressive strength.
\end{abstract}

KEYWORDS: Expanded Polystyrene (EPS), Alccofine 1203, Glass Fiber, Thermoblock \& Compressive Strength

Received: Apr 06, 2019; Accepted: Apr 26, 2019; Published: May 10, 2019; Paper Id.: IJCSEIERDJUN20194

\section{INTRODUCTION}

Concrete technology is growing and many advances and innovations have been made to cope with challenges of many construction aspects. Many productions of lightweight concrete had been designed and among them are by the use of lightweight aggregates and artificial aggregates such as fly ash and slag ${ }^{[1]}$. This project aims at producing lightweight concrete by using the expandable polystyrene. Polystyrene is picked because of its lightweight properties, with great vitality retaining trademark and great warm cover driving fundamentally to non-basic applications ${ }^{[2]}$.

In around the world population increases, the demand for energy and raw materials is growing at a greater pace and has led to the greenhouse gas effect that is responsible to the global climate change. The need for new ecological balance has run to researches into the approval of materials that are eco-friendlier and this has taken about better adoption of plastic based materials in the construction industry.

Expanded polystyrene represents one of such materials that have found their way into the previously conservative construction industry.

Lightweight polystyrene Sandwich block which provides rapid or faster construction and contributes to environmental protection, can provide a solution to many of the above issues and concerns. Heat from sun-based radiation which goes through the divider builds the cooling load. Utilization of stage change material on dividers is probably going to diminish the heat rate by putting away vitality when the stage change process happens.

- $\quad$ About Expanded Polystyrene, Alccofine 1203 and glass fiber 


\subsection{About Polystyrene}

EPS is a shut cell lightweight cell plastics material created from polystyrene. The material has been changed by the expansion of fire-resistant added substances. Polystyrene literally translated is "polymerised styrene".

That is, the single styrene molecules are chemically joined together to form a large molecule which is called the polymer ${ }^{[4]}$. Styrene is delivered from benzene and ethylene, and polymerisation is refined within the sight of substance operator, typically natural peroxides. The expandable shape is delivered as little dots containing a blowing specialist.

Polystyrene is a vinyl polymer. Fundamentally, it is a long hydrocarbon chain, with a phenyl amass appended to each other carbon particle. Polystyrene is delivered by free extreme vinyl polymerization, from the monomer styrene.

Expandable polystyrene (EPS) then is polystyrene in crude dots being steam-warmed, making it extend. Polystyrene has been used mainly in cold countries to make concrete blocks for residential purposes ${ }^{[1]}$.

Expanded Polystyrene (EPS) is a lightweight rigid foam material that is made by the polymerization of styrene nuts and beans.

EPS is a valuable solid material that offers phenomenal protection properties. As the structure of EPS comprises of $98 \%$ air its underlying warm properties are kept up amid its working life. It can be manufactured in a wide range of shapes and sizes ${ }^{[9]}$. Expanded Polystyrene offers a non-hydroscopic and does not readily absorb moisture from the atmosphere. Its shut cell structure diminishes ingestion and movement of dampness it is scentless, inflexible, shut cell Expanded Polystyrene containing 98\% by its volume still air entangled in its cell and is the major reason for its excellent insulation properties ${ }^{[9]}$.

For insulation purpose used of polystyrene major properties of considered like, light weight, High strength, economy, good insulation, Design Versatility, Safety in installation and use, Low Thermal Conductivity would be greater performance.

\subsection{Alccofine 1203}

Alccofine 1203 is ultrafine low calcium silicate product with high glass content with high reactivity obtained through the process of controlled granulation ${ }^{[20]}$. It improves alkanity of concrete. It is one sort of GGBS (Ground Granulated Blast Furnace Slag), which is altered by different synthetic substances which gives more prominent functionality and makes thick pores in concrete. Alccofine 1203 is a mineral additive with low calcium silicate ${ }^{[21]}$. Due to pozzolanic reactivity, it results intensified hydration processes, including latent hydraulic property. Alccofine 1203 grows better pressing thickness of paste creation. It improves strength of concrete parameters at all ages. It is very fine based on Particle Size Distribution (PSD) $12000 \mathrm{~cm} 2 / \mathrm{gm}^{[19]}$. Alccofine has purchased from Ambuja cements and the physical and chemical properties listed below in Table 1 and Table 2

\section{Table 1: Chemical Properties of Alccofine}

\begin{tabular}{|c|c|}
\hline Chemical Analysis & Mass \% \\
\hline $\mathrm{CaO}$ & $32-34$ \\
\hline $\mathrm{Al} 2 \mathrm{O} 3$ & $18-20$ \\
\hline $\mathrm{Fe} 2 \mathrm{O} 3$ & $1.8-2$ \\
\hline $\mathrm{SO} 3$ & $0.3-0.7$ \\
\hline $\mathrm{MgO}$ & $8-10$ \\
\hline $\mathrm{SiO} 2$ & $33-35$ \\
\hline
\end{tabular}


Table 2: Physical Properties of Alccofine

\begin{tabular}{|l|c|}
\hline Physical Analysis & Range \\
\hline Bulk Density & $600-700 \mathrm{~kg} / \mathrm{m} 3$ \\
\hline Surface Area & $12000 \mathrm{~cm} 2 / \mathrm{gm}$ \\
\hline Particle shape & Irregular \\
\hline Particle Size, D10 & $<2 \mu$ \\
\hline D50 & $<5 \mu$ \\
\hline D90 & $<9 \mu$ \\
\hline
\end{tabular}

\subsection{Glass Fiber}

Glass fiber is formed when thin strands of silica based or other formulation glass are extruded into many fibers with small diameters suitable for textile processing. It is material made from extremely fine fibers of glass is a lightweight, extremely strong, and robust material. Its mass quality and weight properties are likewise extremely great when contrasted with metals.

Workability: Glass Fiber used in concrete is reduction in workability. Workability of glass fiber reinforced concrete is affected by fiber aspect ratio and volume fraction as well the workability of plain concrete. As fiber content increase, workability decreases ${ }^{[6]}$.

- $\quad$ Properties of glass fiber ${ }^{[5]}$

\section{- Thermal}

Glass filaments are valuable warm separators due to their high proportion of surface region to weight. In any case, the expanded surface territory makes them substantially more susceptible to chemical attack. By trapping air within them, blocks of glass fiber make good thermal insulation, with a thermal conductivity of the order of $0.05 \mathrm{~W} /\left(\mathrm{m}^{\circ} \mathrm{K}\right)$.

\section{- Tensile}

The strength of glass is usually tested and reported for pristine fibers, those that have manufactured. The thinnest fibers are the strongest because the thinner fibers are more ductile.

The present research work is to improve compressive strength when adoption of expanded polystyrene sheet in concrete block.

\section{EXPERIMENTAL WORK}

Following materials with different function have fulfilled following criteria:

Expanded Polystyrene: Reduce temperature inside face of wall.

Glass Fiber: Repair cracks and better bonding between concrete particles.

Alccofine 1203: Improve better compressive strength when absence of polystyrene volume of concrete deduce.

Figure 1 shows sample of polystyrene sheet and Figure 2 shows polystyrene sheet with reinforcement ring. 

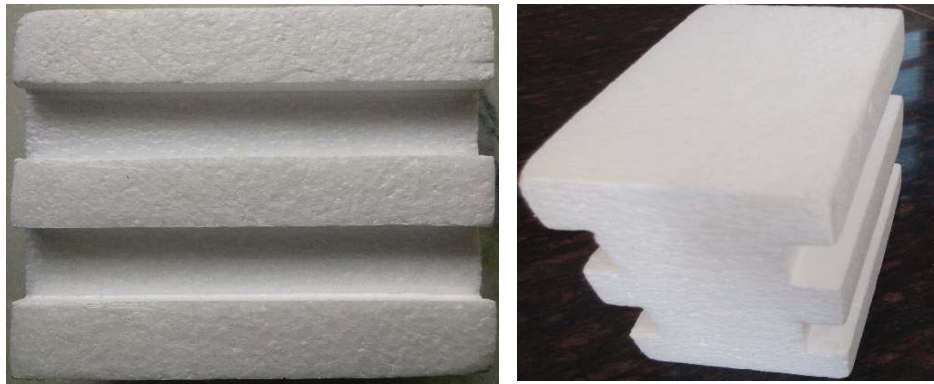

Figure 1: Sample for Polystyrene Sheet

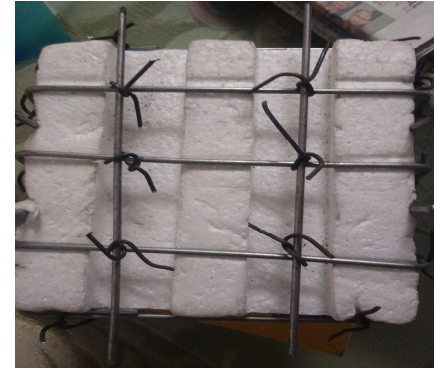

Casting Face

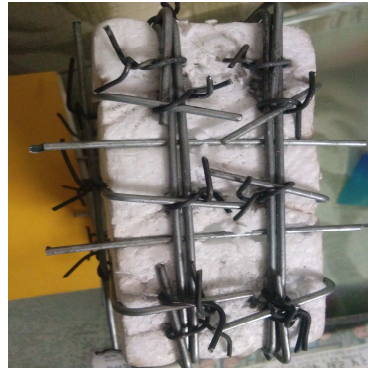

Testing Face

Figure 2: Sample for Polystyrene Sheet with Reinforcement Ring

Figure. 3 and Figure. 4 show casting manor and cross-sectional view of cube.

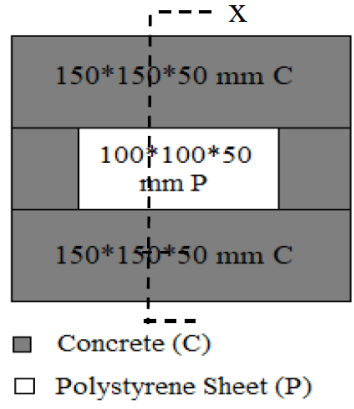

Figure 3: Casting Face of Concrete

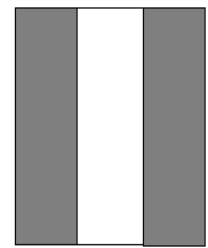

Figure 4: Section View $x-x$ or Testing Face of Block

\subsection{Mix Design}

Mix design was performed for M20, M25, M30, M35 grade concrete followed by IS 10262:2009. Mix design for different Grades mentioned in table 3. 
Table 3: Composition Mix in $\mathrm{kg} / \mathrm{m}^{3}$

\begin{tabular}{|c|c|c|c|c|c|c|}
\hline \multirow{2}{*}{\multicolumn{2}{|c|}{ Cement kg }} & M20 & M25 & M30 & M35 & M35R \\
\hline & & 345.61 & 394 & 428.3 & 469.1 & 469.0 \\
\hline \multirow{3}{*}{$\begin{array}{l}\text { Coarse } \\
\text { Aggregate } \\
\mathrm{Kg}\end{array}$} & 10 & 1073.3 & 628.5 & 617.6 & 604.5 & 603.82 \\
\hline & $\mathrm{mm}$ & & & & & \\
\hline & 16 & - & 419.0 & 411.7 & 403.0 & 402.5 \\
\hline \multicolumn{2}{|c|}{$\begin{array}{l}\text { Fine Aggregate } \\
\mathrm{Kg}\end{array}$} & 719.66 & 702.3 & 690.1 & 675.5 & 674.7 \\
\hline \multicolumn{2}{|c|}{ Water Lit. } & 197 & 197 & 197 & 197 & 197 \\
\hline \multicolumn{2}{|c|}{$\begin{array}{l}\text { Alccofine } 1203 \\
\mathrm{Kg}\end{array}$} & 17.28 & 19.7 & 21.41 & 23.45 & 28.14 \\
\hline \multicolumn{2}{|c|}{$\begin{array}{l}\text { GlassFiber } \\
\mathrm{Kg}\end{array}$} & 5.18 & 5.91 & 6.42 & 7.03 & 4.69 \\
\hline
\end{tabular}

\subsection{Casting}

Cubes of Dimension $150 * 150 * 150 \mathrm{~mm}$ are casted according to the mix proportion and by using Glass fiber and Alccofine 1203.

\subsection{Sample Combination}

Compressive assessment is carried out on different samples as listed below,

- G: Glass fiber polystyrene sheet concrete block -contains $1.5 \%$ fiber.

- AG: Alccofine 1203 fiber polystyrene sheet concrete block- contains $1.5 \%$ fiber and 5\% Alccofine.

- AGR: Alccofine 1203 fiber with reinforced polystyrene sheet concrete block- contains $1 \%$ fiber and $6 \%$ Alccofine with reinforced ring covered at polystyrene sheet.

\subsection{Tests}

\subsubsection{Compressive Strength Test}

Compression test is carried out on cube specimens of size $(150 * 150 * 150)$. After filling concrete into molds at $1^{\text {st }}$ layer $50 \mathrm{~mm}$ thick with tamped by tamping rod. After that fill $100 * 100 * 50 \mathrm{~mm} \mathrm{H}$ grade polystyrene sheet at center of mold and equal fill side space of polystyrene sheet fixed. As well as top layer covered by concrete proper tamping. Molds are vibrated properly in order to avoid the air voids in concrete. Specimens are tested on compression testing machine after 7 , 14 and 28 days of curing.

Testing results are compared to the strength of two bricks. Because of the volume of two brick at similar to the concrete block and its wall unit criteria. As per Indian standard brick strength $7 \mathrm{~N} / \mathrm{mm}^{2}$.

\section{RESULTS AND DISCUSSIONS}

\subsection{Self-Weight of Composition}

We have measure self-weight of normal concrete cube, polystyrene concrete cube and two brick to ensure to the weight of the specimen.

Here, three types of composition to compare weight specified as,

Brick: Weight of two brick because of the similar to the volume of a cube.

PC: Average weight of Polystyrene concrete cube at 28 day 
NC: Average weight of the normal concrete cube at 28 day

Sample weight value plotted graph in Figure. 5 and listed in table 4.

Table 4: Composition Weight

\begin{tabular}{|c|l|c|}
\hline Sr. No. & & $\begin{array}{c}\text { Average Weight } \\
\text { KG }\end{array}$ \\
\hline 1 & Brick & 6.26 \\
\hline 2 & PC & 6.77 \\
\hline 3 & NC & 7.76 \\
\hline
\end{tabular}

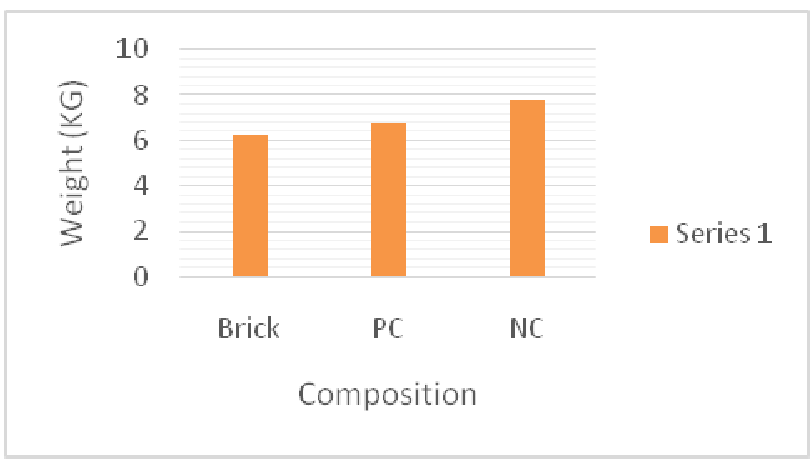

Figure 5: Composition Weight Graph

In this study, to measure the polystyrene concrete cube weight similar to the brick weight and reduced the weight as compared to the normal concrete cube. So, polystyrene concrete cubes another option to brick.

\subsection{Compressive Strength Result}

Compressive Strength result as per calculation listed below in table 5 and plotted graph shown in Figure 6. Here, we have done the compressive tests on different cubes, and we got the average result for different composition for cubes as below:

- For M30 grade two composition M30 G and M30 AG made. In that case, we are getting very less compressive strength for M30 G $\left(9.67 \mathrm{~N} / \mathrm{mm}^{2}\right)$ with respect to $\mathrm{M} 30$ AG $\left(21.80 \mathrm{~N} / \mathrm{mm}^{2}\right)$.

- For M35 grade two composition M35 AG and M35 AGR are made. In this case, we are getting better result for M35 AGR (30.65 N/mm²) with respect to M35 AG $\left(21.34 \mathrm{~N} / \mathrm{mm}^{2}\right)$.

- As compared to Brick, M20 and M25 AG cubes give less or similar result of compressive strength. So, we had tried for M30 and M35 in accordance with better result.

Table 5: Compressive Strength Result

\begin{tabular}{|c|c|c|c|c|c|c|c|}
\hline & $\begin{array}{c}\text { M20 } \\
(A G)\end{array}$ & $\begin{array}{c}\text { M25 } \\
\text { (AG) }\end{array}$ & $\begin{array}{c}\text { M30 } \\
(\mathbf{G})\end{array}$ & $\begin{array}{c}\text { M30 } \\
\text { (AG) }\end{array}$ & $\begin{array}{c}\text { M35 } \\
\text { (AG) }\end{array}$ & $\begin{array}{c}\text { M35 } \\
\text { (AGR) }\end{array}$ \\
\hline \multicolumn{6}{|c|}{ Two brick compressive strength 14 N/mm } \\
\hline $\begin{array}{c}\mathbf{7} \\
\text { Day }\end{array}$ & 7.63 & 15.76 & 6.64 & 10.29 & 11.94 & 16.70 \\
\hline $\begin{array}{c}\mathbf{1 4} \\
\text { Day }\end{array}$ & 9.08 & 22.86 & 7.33 & 17.89 & 16.13 & 26.19 \\
\hline $\begin{array}{c}\mathbf{2 8} \\
\text { Day }\end{array}$ & 12.33 & 24.37 & 9.67 & 21.80 & 21.34 & 30.65 \\
\hline
\end{tabular}




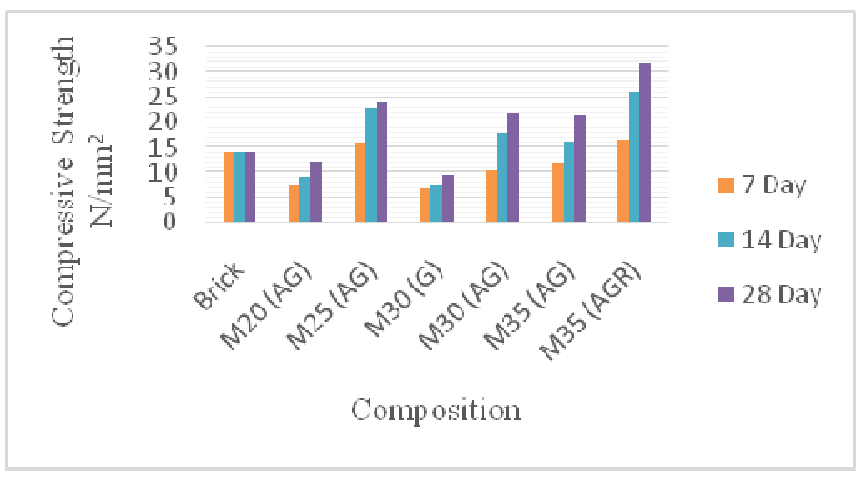

Figure 6: Compressive Strength

\subsection{Thermal Conductivity Test}

To perform the thermal conductivity test by composite wall method procedure was given below,

- $\quad$ Diameter of slabs $(d)$

Base of Concrete: $-0.20 \mathrm{~m}$

Polystyrene: $-0.20 \mathrm{~m}$

Top of Concrete: - 0.20m

- Thickness of slab (b): $-0.075 m$

- Heater: - 400W

- Thickness of Base of concrete plate: $-0.025 \mathrm{~m}$

- Thickness of Polystyrene: - 0.025m

- Thickness of Top concrete Plate: - $0.025 \mathrm{~m}$

- Temperature Indicator: $-0-300^{\circ} \mathrm{C}$

- Ammeter: - 0 - 5A

- Voltmeter: - 0 - 300V

Composite wall Diagram as shown in Figure 7 for guided actual setup of composite wall slab.

\subsection{Procedure}

- Arrange the plates in proper fashion (symmetrical) on both sides of the heater plates.

- See that plates are symmetrically arranged on both sides of the heater plates.

- Operate the hand press properly to ensure perfect contact between the plates.

- Close the box by cover sheet to achieve steady environmental conditions.

- Switch on the supply of heater.

- Give known steady input to the heater with the help of dimmerstat. 
- Keep initially $100 \mathrm{~V}$ for 20 minutes almost and then reduce to $80 \mathrm{~V}$ till steady state is reached so that steady state can be reached within less time.

- $\quad$ Check the input to the heater with selector switch, voltmeter $\&$ ammeter.

- $\quad$ Note down the temperature every 5 minutes till a steady condition is reached.

- Calculate the thermal resistance of the material based on the steady state condition.

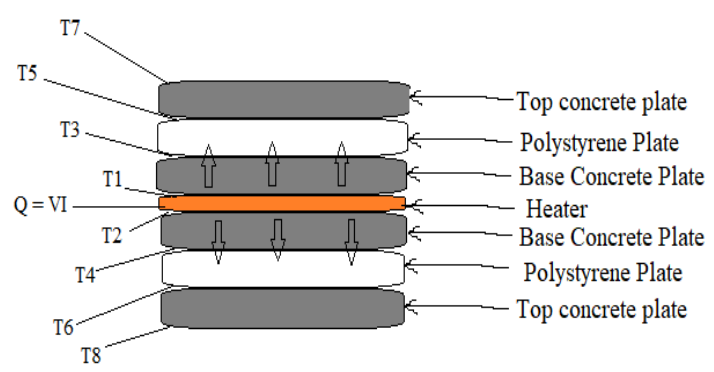

Figure 7: Composite Wall Diagram

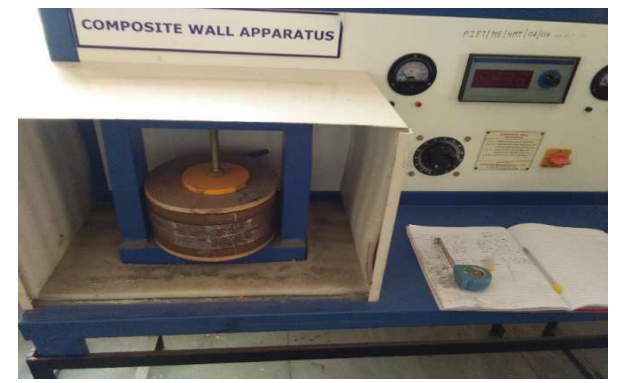

Figure 8: Steady State Composite Wall Apparatus

As per shown in Figure. 7,

Where,

$\mathrm{T} 1$ and $\mathrm{T} 2=$ Centre of plate surface

T3 and T4 = Outside of cast Base concrete Plate/ Inside of Polystyrene Plate

T5 and T6 = Outside of Polystyrene Plate/ Inside of Top concrete Plate

$\mathrm{T} 7$ and T8 = Outside of Top concrete Plate

Table 6: Temperature Reduction Measurement

\begin{tabular}{|c|c|c|c|c|c|c|}
\hline \multicolumn{7}{|c|}{ Voltmeter Reading (V): 106} \\
\hline \multicolumn{7}{|c|}{ Ammeter Reading (I): 0.9} \\
\hline \multirow{2}{*}{$\begin{array}{l}\text { Thermocouple } \\
\text { Readings }\left({ }^{\circ} \mathrm{C}\right)\end{array}$} & \multicolumn{6}{|c|}{$\begin{array}{l}\text { Time }(\min ) \\
\end{array}$} \\
\hline & 5 & 10 & 15 & 20 & 25 & 30 \\
\hline $\mathrm{T} 1$ & 60 & 62 & 65 & 68 & 69 & 69 \\
\hline T2 & 60 & 62 & 64 & 68 & 70 & 70 \\
\hline T3 & 59 & 61 & 63 & 67 & 69 & 69 \\
\hline T4 & 58 & 60 & 63 & 66 & 69 & 69 \\
\hline T5 & 40 & 41 & 42 & 43 & 44 & 44 \\
\hline T6 & 40 & 41 & 42 & 42 & 44 & 44 \\
\hline T7 & 38 & 40 & 41 & 42 & 43 & 43 \\
\hline T8 & 38 & 39 & 41 & 42 & 43 & 43 \\
\hline
\end{tabular}

Testing results of thermal conductivity test listed in table 6 calculation as,

\subsubsection{Rate of heat supply}

$$
\begin{aligned}
\mathrm{Q} & =\mathrm{V} \times \mathrm{I} \\
& =106 \times 0.9 \\
\mathrm{Q} & =95.4 \mathrm{~W}
\end{aligned}
$$




$$
\begin{aligned}
& \mathrm{Ta}=\frac{\mathrm{T} 1+\mathrm{T} 2}{2}=\frac{69+70}{2} \mathrm{~Tb}=\frac{\mathrm{T} 3+\mathrm{T} 4}{2}=\frac{69+69}{2} \\
& \mathrm{Ta}=69.5 \quad \mathrm{~Tb}=69 \\
& \mathrm{Tc}=\frac{\mathrm{T} 5+\mathrm{T} 6}{2}=\frac{44+44}{2} \mathrm{Td}=\frac{\mathrm{T} 7+\mathrm{T} 8}{2}=\frac{43+43}{2} \\
& \mathrm{Tc}=44 \quad \mathrm{Td}=43
\end{aligned}
$$

3.4.2 Total Thermal Resistance of Composite Slab

- $\mathrm{Rh}_{1}=\frac{\mathrm{Ta}-\mathrm{Tb}}{\mathrm{Q}}=\frac{69.5-69}{95.4}$

$$
\mathrm{Rh}_{1}=0.0052
$$

- $\mathrm{Rh}_{2}=\frac{\mathrm{Tb}-\mathrm{Tc}}{\mathrm{Q}}=\frac{69-44}{95.4}$

$$
\mathrm{Rh}_{2}=0.26
$$

- $\mathrm{Rh}_{3}=\frac{\mathrm{Tc}-\mathrm{Td}}{\mathrm{Q}}=\frac{44-43}{95.4}$

$$
\mathrm{Rh}_{3}=0.010
$$

3.4.3 Thermal Conductivity of Individual Materials

- $\mathrm{Rh}_{1}=\frac{\mathrm{L}_{1}}{\mathrm{~K}_{1} \mathrm{~A}}$

$0.0052=\frac{2.5}{\mathrm{~K}_{1} \frac{\pi}{4}(20)^{2}}$

$K_{1}=1.63 \mathrm{~W} / \mathrm{m} .{ }^{\circ} \mathrm{K}$

- $\mathrm{Rh}_{2}=\frac{\mathrm{L}_{2}}{\mathrm{~K}_{2} \mathrm{~A}}$

$0.262=\frac{2.5}{\mathrm{~K}_{2} \frac{\pi}{4}(20)^{2}}$

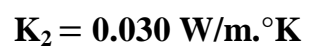

- $\mathrm{Rh}_{3}=\frac{\mathrm{L}_{3}}{\mathrm{~K}_{3} \mathrm{~A}}$

$0.010=\frac{2.5}{\mathrm{~K}_{3} \frac{\pi}{4}(20)^{2}}$

$\mathrm{K}_{3}=0.80 \mathrm{~W} / \mathrm{m} .{ }^{\circ} \mathrm{K}$

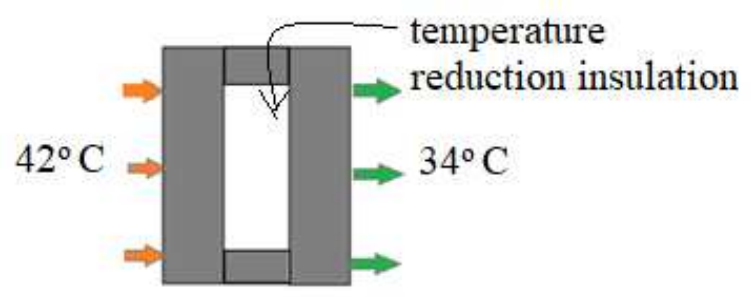

Figure 9: Approximate Temperature Reduction 
- After perform the Thermal Conductivity test to measure the thermal conductivity of top concrete plate, Polystyrene plate, Base concrete plate is $0.80,0.030,1.63 \mathrm{~W} / \mathrm{m} .{ }^{\circ} \mathrm{K}$ respectively.

- In composite wall slab $7.5 \mathrm{~cm}$ thickness for temperature reduction approximately $26^{\circ} \mathrm{C}$ Temperature difference between top slab to base slab. After measure the test we are compare to polystyrene concrete cube approximately $7^{\circ} \mathrm{C}$ to $9^{\circ} \mathrm{C}$ temperature reduction.

- If we have casted Polystyrene concrete cube wall, in that case possible to adopt plaster thickness less than given higher Degree of temperature reduced. Because of the plaster surface more conserve \& store the heat.

\subsection{Cost of Concrete Cube}

Here, we were calculated the cost of concrete cube and compare to the normal concrete cube. Table 7, Table 8 , and Table 9 demonstrate the cost of different composition.

Table 7: M30 Grade Cost for one Polystyrene Concrete Cube

\begin{tabular}{|c|l|c|c|c|c|c|}
\hline Sr. No. & \multicolumn{1}{|c|}{ Material } & $\begin{array}{c}\text { Today's } \\
\text { Market } \\
\text { Price (Rs.) }\end{array}$ & Unit & $\begin{array}{c}\text { Requirement } \\
\text { in One Cube }\end{array}$ & Unit & $\begin{array}{c}\text { Total Rate } \\
\text { in One Cube } \\
\text { (Rs.) }\end{array}$ \\
\hline 1 & Cement & 300 & $50 \mathrm{~kg}$ & 1.20 & $\mathrm{Kg}$ & 7.2 \\
\hline 2 & Sand & 550 & $1 \mathrm{Ton}$ & 2.6 & $\mathrm{Kg}$ & 1.43 \\
\hline 3 & Aggregate & 850 & $1 \mathrm{Ton}$ & 3.2 & $\mathrm{Kg}$ & 2.72 \\
\hline 4 & Alccofine 1203 & 23 & $1 \mathrm{~kg}$ & 62 & $\mathrm{Gm}$ & 1.43 \\
\hline 5 & Glass Fiber & 80 & $1 \mathrm{~kg}$ & 19 & $\mathrm{Gm}$ & 1.52 \\
\hline 6 & $\begin{array}{l}\text { Expanded } \\
\text { Polystyrene } \\
\text { cube (H Grade) }\end{array}$ & ------- & ------- & 1 & One cube & 4 \\
\hline & & & & & Total & Rs. 18 \\
\hline
\end{tabular}

*Approximate value

Table 8: M30 Grade Cost for one Normal Concrete Cube

\begin{tabular}{|c|l|c|c|c|c|c|}
\hline Sr. No. & Material & $\begin{array}{c}\text { Today's } \\
\text { Market } \\
\text { Price (Rs.) }\end{array}$ & Unit & $\begin{array}{c}\text { Requirement } \\
\text { in One Cube }\end{array}$ & Unit & $\begin{array}{c}\text { Total Rate } \\
\text { in One Cube } \\
\text { (Rs.) }\end{array}$ \\
\hline 1 & Cement & 300 & $50 \mathrm{~kg}$ & 1.44 & $\mathrm{Kg}$ & 8.64 \\
\hline 2 & Sand & 550 & $1 \mathrm{Ton}$ & 3.45 & $\mathrm{Kg}$ & 4.3 \\
\hline 3 & Aggregate & 850 & $1 \mathrm{Ton}$ & 4.80 & $\mathrm{Kg}$ & 5.7 \\
\hline 4 & Alccofine 1203 & 23 & $1 \mathrm{~kg}$ & 73 & $\mathrm{Gm}$ & 1.70 \\
\hline 5 & Glass Fiber & 80 & $1 \mathrm{~kg}$ & 21 & $\mathrm{Gm}$ & 1.68 \\
\hline & & & & Total & Rs. 22 \\
\hline
\end{tabular}

*Approximate value

Table 9: M35 R Grade Cost for One Polystyrene with Reinforcement Ring Concrete Cube

\begin{tabular}{|c|l|c|c|c|c|c|}
\hline Sr. No. & \multicolumn{1}{|c|}{ Material } & $\begin{array}{c}\text { Today's } \\
\text { Market } \\
\text { Price (Rs.) }\end{array}$ & Unit & $\begin{array}{c}\text { Requirement } \\
\text { in One Cube }\end{array}$ & Unit & $\begin{array}{c}\text { Total rate } \\
\text { in One Cube } \\
\text { (Rs.) }\end{array}$ \\
\hline 1 & Cement & 300 & $50 \mathrm{~kg}$ & 1.58 & $\mathrm{Kg}$ & 11.38 \\
\hline 2 & Sand & 550 & $1 \mathrm{Ton}$ & 2.27 & $\mathrm{Kg}$ & 1.43 \\
\hline 3 & Aggregate & 850 & $1 \mathrm{Ton}$ & 3.39 & $\mathrm{Kg}$ & 2.88 \\
\hline 4 & Alccofine 1203 & 23 & $1 \mathrm{~kg}$ & 95 & $\mathrm{Gm}$ & 2.18 \\
\hline 5 & Glass Fiber & 80 & $1 \mathrm{~kg}$ & 15 & $\mathrm{Gm}$ & 1.2 \\
\hline 6 & $\begin{array}{l}\text { Expanded } \\
\text { Polystyrene cube }\end{array}$ & ------- & -------- & 1 & One cube & 4 \\
\hline
\end{tabular}




\begin{tabular}{|c|l|c|c|c|c|c|}
\hline & $($ H Grade $)$ & & & & & \\
\hline 7 & Reinforcement & 2 & Meter & 5 & Meter & 10 \\
\hline & & & & & Total & Rs. 33 \\
\hline
\end{tabular}

*Approximate value

- Cost of Polystyrene concrete cube less as compare to Normal concrete cube. If cost of concrete cube compared to the brick, higher to the brick. But, plaster thickness of polystyrene concrete cube is half to the brick that should be possible to reduce cost and maintain the total cost.

- Cost of Polystyrene with reinforcement ring concrete cube as compared to brick very higher. But It should adopt when higher load bearing wall to reduce the thickness of wall is good option.

\section{CONCLUSIONS}

- Alccofine shows better compressive strength of polystyrene concrete block, when volume of cube reduces due to EPS sheet.

- As per result, M30 grade Glass fiber polystyrene Concrete cube (G) compressive strength $9.67 \mathrm{~N} / \mathrm{mm}^{2}$ and Alccofine with glass fiber polystyrene concrete cube (AG) compressive strength $21.60 \mathrm{~N} / \mathrm{mm}^{2}$ at 28 days.

- M15 grade and M20 grade of concrete cube compressive Strength result very less as compared to brick strength so, that should not be adopted to replace of brick.

- M25, M30 and M35 grade of Alccofine with Glass fiber concrete cube (AG) compressive strength result positive to the brick. But, higher load transfer wall M35 grade AGR concrete cube compressive strength result (30.65 $\mathrm{N} / \mathrm{mm}^{2}$ ) much better than all other test results.

- If Polystyrene concrete cube adopted, to reduce the $7^{\circ} \mathrm{C}$ to $9^{\circ} \mathrm{C}$ temperature reduce inside temperature. So, It can reduce the energy cost and make an Eco-friendly product.

- Glass fiber protect the failure of cube through cracks and Alccofine increase compressive strength of cube with excellent bonding that can be measured through the test.

- In any load bearing wall, we can replace the brick with this type of concrete block to improve strength and to reduce the room temperature.

- The relative cost of polystyrene, Alccofine and glass fiber is cheaper than the nominal concrete block due to $15 \%$ reduction in volume of concrete.

\section{REFERENCES}

1. Idawati Ismail, A.Aziz Saim, Abd Latif Saleh "Properties of hardened concrete bricks containing expanded polystyrene beads", Department of Structures and Material, Faculty of Civil Engineering, University Technology Malaysia, Johor, Malaysia (2003).

2. Bischoff P.H etal., "Polystyrene Aggregate Concrete Subjected to Hard Impact", Proceedings-Institution of Civil Engineers, Part 2: Research and Theory, Vol. 89 (1990).

3. M Irsyad, A D Pasek, Y S Indartono, "Heat transfer characteristics of building walls using phase change material" IOP Conf. Series: Earth and Environmental Science Vol. 60 (2017). 
4. S. Ananda Selvan, Dr. P. Asha, "Experimental Study on Lightweight Polystyrene Sandwich Blocks for Replacement of Bricks" International Journal of Engineering Technology, Management and Applied Sciences, Volume 4, Issue 3, ISSN 2349-4476 (2016).

5. Bakhoum, E., Garas, G., \& Allam, M. Sustainability Perspective of Saw-Gang Granite Waste in Concrete Mixes.

6. Ronak Prakashkumar Patel, JayrajVinodsinh Solanki, JayeshkumarPitroda, “A Study on Glass Fibre as an Additive in Concrete to Increase Concrete Tensile Strength” Global Research Analysis, Vol. 2 (2013).

7. T. Sai Kiran, Dr. K. Srinivasa Rao, "Mechanical Properties of Glass Fiber Reinforced Concrete” International Journal of Civil and Structural Engineering Research, Vol. 3, Issue 2, (2016).

8. Iman Asadi, Payam Shafigh, ZahiruddinFitri Bin Abu Hassan, "Thermal conductivity of concrete - A review" Department of Building Surveying, Faculty of Built Environment, University of Malaya (2018).

9. Mathew, H., \& Philip, N. (2015). Strength and Permeability of High Performance Concrete Containing Metakaolin.

10. HamoonFathi, Tina Lameie, Mehdi Maleki, "Simultaneous effects of fiber and glass on the mechanical properties of selfcompacting concrete" science direct in Construction and Building Materials, (2016).

11. McKinley, Alfred and Herbert, H.Shueneman, "Expanded Polystyrene Technology in Construction", Concrete wall building system-The innovative Concrete wall building System Vol. 6 (2017).

12. Pradeepa. S, Anitha.J, N.TamilSelvi, Pranav.P, “A Study on use of Reinforce Thermocol Panels as an Alternate Building Material”, International Journal of Research in Advent Technology (2016).

13. S.Anandaraj, Jessy Rooby, P.O. Awoyera, "Structural distress inglass fiber-reinforced concrete under loading and exposure to aggressive environments" science direct in Construction and Building Materials, Vol. 4 (2018).

14. Sancak, E., Sari, Y. D., \& Simsek, O. (2008). Effects of elevated temperature on compressive strength and weight loss of the light-weight concrete with silica fume and superplasticizer. Cement and Concrete Composites, 30(8), 715-721.

15. K.S. A1-Jabri, A.W.Hago, A.S.A1-Nuaimi "Concrete blocks for thermal insulation in hot climate" Science-Direct in Department of Civil and Architectural Engineering, College of Engineering, Sultan Qaboos University, Oman, Vol. 35, (2014).

16. MaatoukKhoukhi "The combined effect of heat and moisture transfer dependent thermal conductivity of polystyrene insulation material: Impact on building energy performance” Architectural Engineering Department College of Engineering United Arab Emirates University, doi: 10.1016/j (2018).

17. Yuan Fang, BingChen, Sajjad YousefiOderji "Experimental research on magnesium phosphate cement mortar reinforced by glass fiber” Science - Direct in Construction andBuilding Materials, Vol.188, (2018).

18. Sancak, E., Sari, Y. D., \& Simsek, O. (2008). Effects of elevated temperature on compressive strength and weight loss of the light-weight concrete with silica fume and superplasticizer. Cement and Concrete Composites, 30(8), 715-721.

19. Yogesh Iyer Murthy, Apoorv Sharda, Gourav Jain “Performance of Glass Fiber Reinforced Concrete"International Journal of Engineering and Innovative Technology (IJEIT) Volume 1, Issue 6, ISSN: 2277-3754, June 2012.

20. A.Narender Reddy, T. Meena "A Study on Compressive Behavior of Ternary Blended Concrete Incorporating Alccofine" ScienceDirect in Materials Today, (2017).

21. M.Vijaya Sekhar Reddy, K. Ashalatha and K.Surendra "Studies on Eco-Friendly Concrete by Partial Replacement of Cement with Alccofine And Fine Fly Ash” ARPN Journal of Engineering and Applied Sciences, Vol. 11, ISSN 1819-6608, (2016).

22. M. M. Magdum, V. V. Karjinni "Effect of Mineral Ad mixture (Alccofine-1203) on Durability of Hybrid Fiber Reinforced 
Concrete" Indian Journal of Science and Technology, Vol 10(29), (2017).

23. V. R. Panchal, Jay Bhavsar and Vatsal Patel "Performance and Analysis of Brass Coated Micro Steel Fibre on Alccofine 1203 Based Concrete" International Conference on Current Research Trends in Engineering and Technology, Volume 4, ISSN: 2395- 1990, (2018). 
